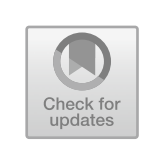

\title{
Historical Memory-Oriented Peace Education and the Sustaining Peace Agenda
}

\begin{abstract}
The sustaining peace agenda, fielded by the UN in the mid2010s, offers an opportunity to take a fresh look at the ways in which we approach our applied, everyday work on and/or for peace in the classroom and beyond. Regarding the field of peace education, there is merit in adopting the less prescriptive, value-laden and universalising and, at the same time, more indeterminate, normatively restrained and humble elements that set the discourse on sustaining peace apart from that of conventional international peacebuilding as we have known it. In this respect, incorporating a focus on historical memory can enhance the strength and value of education on and/or for peace in a world riven with crises, disunity and violent conflict. Rather than upholding notions of universal values, independent of local culture and historically formed power relationships, and the idea that peace can be achieved by righting the individual mind; or seeking to bring about far-reaching social transformation to alleviate the plight of the oppressed and marginalised by empowering them to resist and fight, such an approach strives to enable learners (and teachers) to work towards healing past trauma and recognising the "other" as a moral agent.
\end{abstract}

Keywords Peace education - Historical memory - Sustaining peace agenda $\cdot$ Sustainable Development Goals · Colombia 
Against the backdrop of the discussion of peace education and historical memory presented in the previous two chapters it can hardly be considered to be a straightforward undertaking to make the case, as this chapter does, that historical memory should be made a central part of peace education, particularly in countries wrestling with, or emerging from, violent conflict. Before developing my argument in support of historical memory-oriented peace education a brief recapitulation of the main points made earlier is therefore in order. Recall that both peace education and historical memory are terminological constructs that are each composed of two contested and hard-to-nail-down conceptspeace/education and history/memory. Authors who are not convinced by the claim that peace education is inherently and by itself desirable (and effective) point to the need of paying more attention to "the reciprocity of its two fundamental concepts" as well as the "relation between power and violence" and the "fruitful tension between peace and freedom" (Gur-Ze'ev 2010: 172). As I have shown, both the conventional and the critical schools of peace education fall short, each in their own way, of fully living up to this challenge.

With their normative, apolitical, morally appellative and culturally universalist focus on the individual learner, conventional conceptions and practices of peace education do not easily relate to the variable, heterogeneous and context-dependent notions and realities of peace and education that can be found across the globe. They also shy away from taking account of often entrenched asymmetric and unequal power relationships between social, ethnic and other groups that typically characterise violence-inflected societies, thereby circumscribing the possibility to contribute through education to the creation of more inclusive and democratic institutional structures that enable peaceful coexistence beyond the mere absence of direct, structural and cultural forms of violence. Critical approaches to peace education, in turn, forefront the importance of empowering individuals as well as collectives to become agents of social transformation, especially at the local level. In this perspective, education for peace is understood as social action geared towards finding structural solutions to a broad range of direct, cultural and structural manifestations of violence and inequality. Yet, while critical peace education is more attuned to the thorny issues of power and exclusion, and pays more attention to social inequality and other structural drivers of violence, it is faced with the challenge of showing convincingly how the empowerment and emancipation of the marginalised and oppressed through formal and 
informal education for peace can lead to broader collective and institutional transformation that respects the freedoms and rights of all members of communities ravaged by violence.

With respect to historical memory, I have highlighted that the term risks coming across as a paradox or tautology, principally because of the uneasy and undetermined relationship between history and memory. The term historical memory is thus characterised by ambiguity and ambivalence. Composed of two contested concepts, it lends itself to various different interpretations and uses, including being instrumentalised by hegemonic interests and powers in the pursuit of the creation of "canonical version[s] of history, as well as a Manichean division of the historical characters into good and evil" (Bull and Hansen 2016: 2). Instead of contributing to healing and addressing the traumas of the survivors of violence and atrocious crimes, such antagonistic and/or particularistic historical memory strategies seek to recover and preserve the memories of the (self-proclaimed) victors or victimisers at the expense of those of the victims. Exploiting the subjective and malleable character of memory, both individual and collective, politically and/or ideologically motivated approaches to historical memory, which invariably are weak on history, are exclusionary and one-sided. They cement societal divisions, perpetuate "inherited hatreds" (Sánchez 2006) and strategically promote the intergenerational transmission of victimhood and trauma of merely one side of the violent conflict. They obstruct the formation of new inclusive identities. In short, when historical memory work is hijacked by the powerful it seriously risks not contributing to the goals of fomenting the possibility of peaceful coexistence, perhaps even reconciliation, in violence-inflected societies.

Given the risks and tensions that are associated with both peace education and historical memory, the reader may well wonder what the point is of adding to the prevailing complexity by arguing for the relevance and usefulness of historical memory-oriented peace education. Does such a quixotic endeavour not open the doors to complicating matters even more, rendering the task of educating on and for peace an utterly impossible one? As I strive to explain below, I do not think so. Although historical memory-oriented peace education as I propose it here is not a silver bullet, it nonetheless can help address the mentioned shortcomings of both conventional and critical peace education, offering new perspectives on how to approach the demanding issue of peace in the classroom. The remainder of this chapter substantiates the argument in 
support of historical memory-oriented peace education and offers some thoughts on how peace education framed in these terms relates to the emerging international agenda on sustaining peace fielded by the UN in the mid-2010s.

\subsection{Historical Memory-Oriented Peace Education: Why and How}

As so often in my academic work, I draw inspiration not only from scholarly debates and professional curiosity but also from my own experience as I have lived and felt it over the years. As briefly narrated in the introduction and subsequent parts of this book, regarding education for peace and historical memory the element of personal experience relates foremost to my work as a lecturer at a Colombian university between 2014 and 2019 and my participation in CNMH's historical memory work with the Colombian armed forces. My previous long-term engagement as a political analyst with the International Crisis Group and as a post-graduate researcher in Latin America too informs the present account.

Based on my classroom experience in Cali, it is worthwhile recalling that when faced with difficult-to-grasp and intricate problems of violence and peace, students would intuitively take recourse to their own experiences, and their memories thereof, in order to imbue abstract notions like conflict, security and peaceful coexistence with concrete meaning and palpable substance. This would typically take the form of brief oral narratives, spontaneous interjections by individual students, if you wish, in the flow of the classroom work, aimed at sharing with the group knowledge about specific past events involving different forms of violence. These short elaborations on traumatic and/or distressing events, which had either affected the student personally or someone in their family or wider social environment, conjured up vivid images of what it feels like to suffer, for instance, abduction at the hands of the insurgents or criminal organisations or intimidation and stigmatisation by local authorities. Although the pedagogical concept of the courses I taught at the time did not explicitly include the elaboration and use of personal narratives as a means to enhancing and deepening students' understanding of violent conflict and peace in Colombia and elsewhere, the dialogic nature of the learning activities developed in the classroom appears to have provided an appropriate space for them to come to the fore autonomously and spontaneously. In my role as the teacher, I would pay attention to 
these recollections, seeking to explore them in conversation with the students and linking them to the broader topics of violence and peace we were working on in the specific session as well as throughout the course. Sometimes the shared narratives and our conversations about them caused apprehension and disbelief among the listening students, on other occasions they invited controversial debate.

I do not intend here to draw any generalisable conclusions from this brief anecdotal description of my teaching experience in Cali. That would not be appropriate and expedient. However, I believe my observations can serve as a backdrop to the following discussion of the relevance and usefulness of incorporating historical memory into education on and for peace, especially in societies affected by protracted violence, glaring injustice and deep social, political, ethnic and other cleavages. To begin with, recognising both the potential and real pitfalls of historical memory work that I previously analysed in some depth in relation to the case of Colombia, I suggest that approaching peace education through the lens of historical memory has certain distinct advantages vis-à-vis the conventional and critical schools. One such advantage is that historical memory-oriented peace education foments learning along the two axes of "emotion-understanding" as well as "individual-social" (Corredor et al. 2018: 178). Student (and teacher) narratives of traumatic or unsettling past experiences related to violent conflict and their carefully guided discussion in the classroom, even if controversial, make room for the voicing of emotions. This enhances the possibilities of strengthening understanding among students, of finding the underlying cause of intricate and often abstract or unfamiliar concepts like peace. At the same time, applied historical memory work in the classroom challenges learners to witness, through the accounts of their peers, events of the past that owing to their traumatic and painful nature have left traces in learners' (and teachers') present consciousness. Engaging with these accounts in critical classroom discussion is likely to generate controversy, while at the same time it is likely to direct the spotlight away from the individual case to the broader social and institutional structures that enabled or at least framed the past experiences as narrated by students.

None of these processes are automatic and there are several factors that potentially impinge on the feasibility and effectiveness of historical 
memory-oriented peace education. ${ }^{1}$ This notwithstanding, I suggest that facilitating and stimulating learning in this fashion can help transcend the formulaic nature of normative, morally appellative and universalising approaches of conventional peace education. Rather than focussing classroom activities and learning contents on individual attitudes, beliefs, behaviours and values and how they can and should be "changed," according to universalist, often abstract conceptions of non-violence, peacefulness, tolerance and democracy, the work to be conducted is instead anchored in the lived and felt experience of learners (and teachers). On the basis of this grounding, which includes an emotional dimension and reflects realities as they are lived by individuals and their families and communities on a daily basis, it then becomes possible to establish, through guided classroom conversations and dialogue and by taking recourse to the relevant academic and testimonial literature, the links between individual experiences of different types of violence and injustice and the broader institutional setting or political and social order in which they pan out. Furthermore, not working on the basis of established, universalist moral premises of "good" versus "bad" or "just" versus "unjust," which seek to differentiate between "us" (the good and virtuous) and "them" (the bad and evil), education on and for peace anchored in students' (and teachers') personal memories of violence and injustice can support the "comprehension of other people's goals and circumstances as moral agents, which [in the classroom] helps to develop moral agency" (Corredor et al. 2018: 176; see also Manojlovic 2018).

\footnotetext{
${ }^{1}$ For instance, not all countries wrestling with, or emerging from, violent conflict are similarly well equipped with regards to the availability and accessibility of historical memory work, including a plurality of narratives of the conflict and testimonial literatures. I would argue that among the contemporary cases Colombia is quite unique in this respect. As mentioned above, the results of the work conducted by GMH and CNMH is extraordinarily impressive in terms of the number of reports that have been elaborated, the depth and thematic breadth of the reports and the ample diffusion of the generated knowledge, including through pedagogical and didactic materials. Other factors that impinge on the feasibility and effectiveness of historical memory-oriented education on and for peace are constraints owing to apprehension or unwillingness among students and their families to discuss and engage with a painful past. As has been reported from Guatemala, the reasons for this can be manifold, ranging from concerns about students' safety and not wanting to expose young learners to the knowledge about past atrocities to the persistence of deep animosities and patterns of polarisation across different social and ethnic groups (Bellino 2014).
} 
Likewise, historical memory-oriented education on and for peace, as I understand it, can help address the limitations and shortfalls of critical approaches. As someone who has spent many years working and teaching in violence-inflected societies, I am of the view that peace educators in such settings do not have much of a choice but to adopt a critical perspective. In this regard, it cannot be over-emphasised that the omnipresence and "naturalisation" of diverse manifestations of direct, structural and cultural violence and injustice are indeed overwhelming. ${ }^{2}$

${ }^{2}$ Here, I wish to take the liberty to offer a personal reflection on the relevance of critical, historical memory-oriented education not only in countries and societies that are witnessing violent conflict or where such conflict has been occurring for several decades and is still ongoing, such as Colombia, but also in those where unspeakable atrocities and crimes were committed by states and social systems that today appear to be better positioned to look their dark past in the eye, such as Germany. I do not have the space here to go into any great detail. But based on my own experience as a high school student in West Germany from the late 1970s up to the mid-1980s, I would argue that following the end of the Nazi regime in 1945 and the creation of the two German states in the East and West it would have made all the sense there is to see the instalment of critical, historical memory-oriented education at high schools and universities. While in West Germany-and I can only speak of West Germany-history textbooks were rewritten to include "objective" accounts of the atrocities of the past (Galtung 2017), I have no recollection whatsoever of us, the high school and later university students, ever being asked by our teachers what we and our families and people in our social environments knew, remembered or felt about the holocaust and the unspeakable crimes that had been committed by Nazi Germany. Or, for that matter, what we knew, remembered and felt about the suffering that the war had meant for our parents, grandparents and wider families and social circles. This conversation just did not happen in the classroom. The emphasis was on transmitting the historical facts about something terrible that had occurred decades ago. Nazi Germany and its crimes were not considered to be themoral-business of the younger generations in any deeper sense. Buttressed by an official discourse and culture of repenting remembrance in which the West German state and our teachers took pride we were expected to subscribe to a pledge of "never again." Yet that what had happened was not addressed as a concern of the present, of German society as we were experiencing it. The past was the past. All around people were claiming-and still are - that they and their kin and friends had nothing to do with it, regardless of whether that was true or not, that they abhorred the Nazi regime and its crimes, that the Nazis had been someone "other" (see Leo 2021). Teaching the history about it and keeping an official version of memory of it alive was deemed to be imperative-and sufficient. As unsatisfactory as my own high school and university experience was with respect to the one issue that surely must shape the identity of any German citizen of my generation (see Leo 2021) I would argue that the failure of not addressing a horrid national past through historical memory-oriented education was likely even more pronounced among the generation of my parents, who were either born just before the onset of the holocaust and the war or in the midst of it. I do not have any hard scientific evidence, and this is really inappropriate to acknowledge for someone who is in the academic writing business. 
In Colombia, for instance, even the most "academic" of peace and conflict researchers and pedagogues are unable to remove themselves from this harsh reality. If they are serious about what they are doing they will not be able to look the other way, underestimating or denying the violence and suffering, however subtle, that manifests daily on their doorstep and on the way to university and back home, often early in the morning and late at night. ${ }^{3}$ Like the actual victims and survivors of violence it touches them directly. Furthermore, it is a known if understudied fact that academics in Colombia and other violence-inflected countries in Latin America and elsewhere who are critical of the status quo or get themselves into public disputes with those wielding power have been attacked and/or killed. Others suffer institutional and social marginalisation and ostracism. ${ }^{4}$ Hence, it is not surprising that educators and researchers who pursue peace agendas in such settings would intuitively, and as a matter of

But judging by the oral, often emotional histories of both trauma and distancing that I have been hearing throughout my life in my family and wider social environment, I daresay that there cannot have been much processing of the past through critical, historical memory-oriented education among the generation of my parents either. One cannot but wonder, therefore, whether the manifold present-day manifestations of disdain for those who are deemed to be different because of their language, culture, gender and tone of skin colour, in short, the daily manifestations of nationalism, antisemitism and racism that German society is presently witnessing are not related to that lack of dealing with the country's past by systematically working with historical memory approaches in and outside of the classroom-instead of emphasising, decade after decade, the purported strengths of academic historiography and the unassailable virtues of the official discourse and culture of remembrance.

${ }^{3}$ For the sake of proper contextualisation it is worthwhile to note that in countries such as Colombia it is not uncommon that full-time university lecturers, that is, those few academics who are in the privileged position to make a decent living out of their higher education work, often start at 7 a.m. in the morning and finish at 10 p.m. at night. These long working hours, which typically also include teaching on Saturday mornings, have to do with heavy teaching loads and teaching on executive Master programmes, which universities commonly offer on Fridays from 6 to 10 p.m. and Saturdays from 8 or 9 a.m. till noon. Before the outbreak of the COVID-19 pandemic, which forced educational organisations worldwide to switch to online teaching/learning, full-time faculty at Colombian universities were principally requested to be present in their institutions every working day.

4 To my knowledge, this is an understudied topic. As important as it is we know more about the plight of journalists, human rights defenders and other civic advocates and activists than about that of critical academics. Critical scholars and educators are often also active human rights defenders, but I think it would be important to look at them specifically as academics who suffer the consequences of going against the grain in their writing and in the classroom. 
both moral principle and survival, adopt critical peace education perspectives. Central to their work is putting the victims and survivors of violence and injustice as well as the defence of their fundamental rights up front and centre stage in the attempt to counter-balance and work towards the transformation of political and social orders built on patterned violations of human rights and the employment of violent means to safeguard particularistic, often downright criminal or crimilegal interests (see, for instance, Arias 2016; Corredor et al. 2018; Herrera and Pertuz 2016; Merchán 2016; Schultze-Kraft 2019, 2021).

Yet centring the attention squarely on the victims and survivors of direct, structural and cultural manifestations of violence and injustice, and unequivocally taking sides with them, risks deepening prevailing antagonisms and animosities among students by promoting perspectives and courses of action that may be perceived as one-sided and as too radical or idealistic in their transformational aspirations. I suggest that in violence-inflected settings, such as Colombia, where complex, dynamic and multi-layered constellations of violent conflict have been manifesting simultaneously with variable intensity for more than half a century, it is no straightforward undertaking at all to take sides. Of course, and lest I not be misunderstood, it is of the utmost importance to denounce and condemn the atrocious crimes and human rights violations committed by the state, especially by elements of its military and police, paramilitary organisations, criminal groups and the insurgents. Over decades, this is what Colombian human rights organisations and victim associations have been doing. ${ }^{5}$ However, when it comes to education on and for peace the ballgame changes.

Exploring and making use of the above-mentioned healing quality of historical memory work is of particular significance in the classroom. Provided the classroom is endowed with the qualities of a safe and inclusive space, which is not always easy to achieve, working with techniques such as oral histories, personal narratives, remembering and futures visioning have the power to contribute to overcoming the false dichotomy

5 It should be noted that in a state like Colombia, which in formal terms is democratically constituted but faces many de facto challenges regarding the application of the rule of law, political representation and equitable and inclusive development, human rights groups and victim organisations are up against powerful, unyielding and often criminal or crimilegal interests. Yet, this does not mean that-depending on the case, issue and prevailing political constellation-they cannot find ways to enlist the support from relevant state entities, such as the ombudsman's office and the high courts. 
between forgetting and remembrance. They can also help bridge the gap between the individual learner and their institutional and social environment because such techniques are instrumental in bringing to the fore that peaceful coexistence and reconciliation do not depend only-or mostly-on students' personal attitudes, beliefs, behaviours and values but are also shaped to significant degrees by the prevailing social and political orders, that is, systems of domination (Schultze-Kraft 2019). In this vein, historical memory-oriented education on and for peace promises to address one of the salient pitfalls of critical approaches to peace education in violence-inflected societies by offering a stronger theory of change with respect to promoting broader, pro-peace social transformation. Historical memory-oriented peace education is more cognisant about, and sensitive to, the complex, dynamic and multi-layered characteristics of violent conflict. I therefore suggest it enables learners to envision and take transformative social action beyond the classroom in affirmative, considerate and more persuasive and legitimate ways.

Employing the tools of narrative, oral history, remembering and futures visioning is a recurrent topic in the literature on peace education (see, for instance, Bekerman and Zembylas 2008, 2012; Boulding 2002; Corredor et al. 2018). In what follows, I briefly summarise why I believe these specific learning techniques, which evidently do not cover all of the tools peace education has at its disposition, ${ }^{6}$ can be particularly useful when they are combined with, and grounded in, historical memory work. ${ }^{7}$ To illustrate my arguments, I look again at Colombia, though this South American nation may be a somewhat singular case because unlike other countries wrestling with, or emerging from, violent conflict there is a vast body of historical memory work that can fruitfully be used in the classroom, both as a source and an illustrative example. The work of GMH and CNMH in the past 15 years has highlighted the centrality of listening to the victims and survivors of past atrocities and injustice, recollecting and documenting their memories and putting them into interplay with historical research on Colombia's violent conflict. Throughout, the

\footnotetext{
${ }^{6}$ For other techniques and tools see, for instance, Hagar and Mazali (2013), Kelly and Kelly (2013), and Goulah and Urbain (2013).

7 This does not mean, of course, that conventional and critical approaches to the field ought to be jettisoned altogether. Rather, while incorporating a focus on historical memory is relevant in its own right, it also serves as a backdrop to the enhancement and critical interrogation of the more established modes of peace education.
} 
overarching aim of this monumental endeavour has been to generate "an inclusive and integrative narrative, in tune with the voices of the victims, on the origin and evolution of the internal armed conflict in Colombia" (author's translation) (GMH cited in Riaño and Uribe 2017: 16). Note that the emphasis is on creating an inclusive and integrative narrative, not a homogenising one.

As discussed earlier, this interpretation of its mandate led $\mathrm{CNMH}$ to take the-daring and risky - step to work with the Colombian military and police on historical memory at the War College. The ensuing dialogue turned out to be difficult and fraught with tensions. However, in spite of these problems CNMH and less intransigent elements of the armed forces sought and found ways together to continue their cooperation-in the classroom as well as with respect to the recovery and documentation of soldiers' memories of victimhood. ${ }^{8}$ I believe that on the whole this has been a valuable experience capable of informing the use of oral history and narratives as pedagogical and didactic tools in education on and for peace. CNMH's commitment and openness to engaging educationally with the state's armed forces reflects a resolve to put into practice what Zvi Bekerman and Michalinos Zembylas call "contested narratives" and "dangerous memories" (Bekerman and Zembylas $2008,2012)$. According to the two noted peace education scholars, "teaching contested narratives through critical pedagogies is to disrupt those regimes of feeling and thinking that perpetuate a conflicting ethos with others, and to invent new practices of relating with them" (Bekerman and Zembylas 2012: 41). Working with "contested narratives" in the classroom also means to make room for the articulation of "dangerous memories," that is, memories that "are disruptive to the status quo" embodied in the "hegemonic culture of strengthening and perpetuating existing group-based identities," which are "usually essentialised, static and tribalistic" (Bekerman and Zembylas 2008: 126; see also Manojlovic 2018).

Yet contrary to what might commonly be assumed the Colombian experience with historical memory work reveals that contested narratives and dangerous memories did not only arise from among the victims

8 At least until the end of the Santos administration in August 2018, when the new government of President Duque took office and Colombia's political context witnessed notable change taking the country once again off the course of pursuing peace (Sánchez 2019). 
and survivors of violence and injustice but also from among sectors of the state that felt underrepresented or excluded from the officially sanctioned efforts to recover and preserve the historical memory of more than half a century of violent conflict. This shows that historical memory work is not always the preserve of hegemonic powers and interests, but it can also prompt just these powers and interests to respond and let themselves be taken into participating, even if in the role of those who contest and protest, in the quest for historical clarification. This is a lesson that should not be underestimated when designing historical memoryorientated learning activities in the classroom. Contested narratives and dangerous memories are likely to emerge on all sides of the violent conflict spectrum. They may not always reflect a prevailing "hegemonic culture" (Bekerman and Zembylas 2008: 126). Recognising that in itself this is not a negative but a positive and necessary element of education on and for peace strikes me to be central. Evidently, and that is a caveat that must not be ignored, learners' narratives, both contested or not, and memories, both dangerous or not, ought to be brought to bear and helped to develop their healing power in such a way that they do not add to prevailing patterns of animosity and antagonism among students. While teachers have responsibility in this regard, they also need caring and dedicated institutional support to be able to navigate safely the rapids that are bound to emerge in the classroom-and beyond. ${ }^{9}$

Working with learners' narratives and oral histories in historical memory-oriented peace education-which, depending on the variable richness and accessibility of academic and testimonial sources in any given setting of violent conflict and/or state crime, ought to be critically acclaimed and/or interrogated against the backdrop of the broader historical context-can be complemented and enhanced by employing the tool of remembering as a function of futures visioning. As Elise Boulding describes based on her own praxis of conducting futures visioning or imaging workshops in the United States, the idea behind this type of exercise is to take people into the future, say, 20 or 30 years from the

${ }^{9}$ Here again I write on the basis of personal experience. At the Colombian university where I taught there was little institutional support for teachers, especially expatriate or international ones, who were working with students on the thorny issues of violence, armed conflict and peace. The onus of keeping things in check and making them work was very much on the teachers, who sometimes were confronted with indifference, distrust or even animosity on the part of the university hierarchy, their peers and students (SchultzeKraft 2021). 
present, and work with them on the "imaginative exploration of 'how things worked' in that future, followed by a remembering, looking back from this future to the present to imagine how all this peaceableness had come about" (Boulding 2002: 51). Futures visioning of a more peaceable world, coupled with an effort of imaginative remembering of what it took to get to such an improved condition and what individuals and collectives contributed to this process, is geared towards building students' (and teachers') skills to explore actively what they could do now, in a present riven with violence and injustice in order to transform individual attitudes, beliefs, behaviours and values as well as social and institutional structures. In other words, futures visioning and remembering may help to bridge the prevailing gap in education on and for peace between the individual and the social-institutional realms. I suggest that experience with historical memory-oriented education supports students and teachers to conduct futures visioning and remembering exercises.

\subsection{The Sustaining Peace Agenda: What Is IN A Term}

One does not have to subscribe to David Chandler's pointed observation that "peacebuilding is no longer a term on the international agenda" (Chandler 2017: 6) to note that for some time now we have been witnessing shifts in the global policy discourse on violent conflict and peace. Concomitant to the adoption of the SDGs and the Paris Agreement on climate change, among the landmarks of this ongoing process are the report of the Advisory Group of Experts for the 2015 review of the United Nations peacebuilding architecture (UN General Assembly and Security Council 2015a) and the attendant UN General Assembly and Security Council resolutions of April 2016 (UNGA 2016; 
UNSC 2016). ${ }^{10}$ Initiated under the auspices of outgoing UN SecretaryGeneral Ban Ki-Moon (2007-2016), the quest for evolving international peacebuilding towards a new paradigm of sustaining peace has since commanded the attention of his successor, António Guterres (2017 to present).

In short, the semantic shift from building to sustaining peace, which is applied in flexible fashion in the relevant official documents, reflects mounting concerns within the UN, its member states and other multilateral bodies, including the World Bank, about the effectiveness, costliness and legitimacy of international peace operations. Framing the issue as one of sustaining rather than building peace seeks to "shift the debate away from liberal top-down problem-solving approaches towards more pluralistic bottom-up, or hybrid, conflict management approaches that do not have the ambition to resolve conflict, but instead invest in the resilience of local social institutions to prevent, cope with and recover from conflict" (de Coning 2016: 167). ${ }^{11}$ The task of sustaining peace is understood to involve close policy alignment with the SDGs, particularly Goal 16 on peace, justice and strong institutions but also Goal 4 on quality education. It also entails reforms of the New York-based peacebuilding organisations, established in 2005 and comprising the Peacebuilding Commission (PCB), the Peacebuilding Fund (PBF) and the Peacebuilding Support Office (PBSO), and more effective coordination and cooperation between the UN's peace and security, human rights and development pillars.

10 The Advisory Group of Experts was established, in January 2015, by UN SecretaryGeneral Ban Ki-Moon at the request of the Presidents of the UN General Assembly and the UN Security Council. It was chaired by Gert Rosenthal (Guatemala) and integrated by Anis Bajwa (Pakistan), Saraswathi Menon (India), Funmi Olonisakin (Nigeria), Ahmedou Ould-Abdallah (Mauritania), Charles Petrie (France) and Edith Grace Ssempala (Uganda). The group's final report was presented on 29 June 2015. The 2015 review was preceded by a first, more limited one in 2010. A third comprehensive review was launched in October 2019. At around the same time as the Advisory Group of Experts the secretarygeneral also convened a High-level Independent Panel on Peace Operations to undertake a review of United Nations peace operations. The panel presented its final report on 17 June 2015 (UN General Assembly and Security Council 2015b).

11 "Resilience" is a key term in the lexicon of the sustaining peace agenda, but there is not one single, accepted definition. Philippe Bourbeau refers to resilience as meaning "the process of patterned adjustments adopted by a society or an individual in the face of endogenous or exogeneous shocks (emphasis added)" (Bourbeau, cited in Chandler 2017: 166). According to Chandler, "resilience increasingly [focuses] on working with and upon the capacities, capabilities, processes, and practices already 'to hand' rather than the external provision of policies or programmes" (Chandler 2017: 166). 
Echoing seminal earlier assessments, such as the World Development Report 2011 on conflict, security and development (World Bank 2011) and foreshadowing others, such as the joint UN-World Bank report on pathways for peace (UN and World Bank 2018), the seasoned experts behind the 2015 review of the peacebuilding architecture attested the UN to be operating based on a "generalised misunderstanding of the nature of peacebuilding" (UN General Assembly and Security Council 2015a: 3). In an era of increasing violent conflict occurrence ending the cycle of conflict decline that had set in towards the late 1990s, the task of building peace could no longer be left as an "afterthought: under-prioritised, under-resourced and undertaken only after the guns fall silent" (UN General Assembly and Security Council 2015a: 3). Ever more complex and intractable intrastate conflicts-increasingly involving violent extremism and organised crime and driven by a mix of institutional fragility, bad security and other governance, corruption, a politics of exclusion, widespread poverty and inequality, environmental degradation and a deadly struggle over access to scarce natural resources-were not amenable anymore to being addressed by outside interventions along the sequential arc of peacemaking-peacekeeping-peacebuilding. According to the group of experts, comprehensive peace accords between "fairly wellidentified enemies" represented an "old model" of ending conflicts, which more recently "has often had to give way to less tidy arrangements" (UN General Assembly and Security Council 2015a: 13). In light of these challenges and new realities, the PBC, PBF and PBSO, as well as the wider institutional set-up of the UN's peace and security pillar and its linkages to the human rights and development domains, had to undergo reform and be made fit for purpose (UN General Assembly and Security Council 2015a).

As it appears, the experts' findings hit a nerve. With the issuance of the twin UN General Assembly and Security Council resolutions on the peacebuilding architecture in April 2016 (UNGA 2016; UNSC 2016), the UN's response to the described conundrum began to crystalise around the notion of sustaining peace. For the world's largest inter-state organisation this has meant foremost striving to come to grips with institutional shortcomings and entrenched governance problems of coordination and cooperation, both within the organisation and between it and the member states. Assuming personal leadership in this arduous process, since 2017 Secretary-General Guterres has overseen the restructuring of the UN's peace and security pillar, seeking to reorganise 
it internally and strengthen linkages or establishing new ones to the development and human rights domains. Details about these efforts are presented regularly in his annual reports on peacebuilding and sustaining peace (UN General Assembly and Security Council 2018, 2019, 2020). These reports are replete with specific information about the measures taken to enhance the UN's operational and policy coherence as well as its leadership, accountability and capacity, guarantee adequate financing for building "peaceful and resilient societies" (UN General Assembly and Security Council 2019: 1), and strengthen partnerships with regional and subregional organisations, the international financial institutions and civil society, including youth and women's groups in conflict-affected countries. References abound to alignment, cross-pillar collaboration, mainstreaming, conflict-sensitive responses, national ownership, wholeof-society and holistic approaches, inclusive and sustainable development, local resilience, and so on.

Beyond the UN and the broader inter-governmental environment, the new focus on sustaining rather than building peace has been met with both interest and critical interrogation. Aiming at cutting through the fog surrounding this major work-in-progress, the UN's sustaining peace agenda has sparked a flurry of activity on the part of academics and analysts of global affairs (see, for instance, Cahill-Ripley and Hendrick 2018; Chandler 2017; de Coning 2016; International Peace Institute 2017a, b, 2018; Kustermans et al. 2021; Metcalfe-Hough et al. 2017; Ponzio 2018; Pugh 2021). If there is one common denominator in this variegated stream of analysis and commentary, it is the tacit consensus that international peacebuilding as a rationally enlightened global governance project rolled out in the aftermath of the fall of the Berlin Wall and the crumbling of the Soviet Union is reaching its limits. In view of the renewed spike in armed, mostly intrastate conflict in the second decade of the present millennium, it is acknowledged that a different approach to promoting peace is needed. Yet whether the UN-led shift towards sustaining peace will be able to fill the void of conventional "liberal" peacebuilding and end its "twenty years' crisis" (Chandler 2017) is subject to dispute.

Throwing their weight behind the sustaining peace agenda, some observers hold that the key challenge lies in finding ways to operationalise it across the UN's three pillars and develop concrete new policy options - to be devised and implemented foremost by national governments in cooperation with civil society and other non-state organisations. 
In this scenario, the international community's role is limited to offering national governments a helping hand through political and other facilitation or mediation geared towards strengthening local resilience in the face of violent conflict or efforts to prevent it. ${ }^{12}$ Hence, the new order of the day is conflict management and working with national and/or local institutions and structures already in place that are amenable to supporting peaceful change and reconciliation, not externally engineered conflict resolution and the pursuit of the mirage of a "liberal" peace (see, for instance, International Peace Institute 2017a, b, 2018; MetcalfeHough et al. 2017; Ponzio 2018). Other analysts, however, question this view, contending that the notion of sustaining peace is still not sufficiently elaborate and theoretically substantiated to serve as a compass to re-orient efforts to promote peaceful conflict management in violenceravaged countries (de Coning 2016). For this to be achieved, it would first be paramount to gain a deeper understanding of complexity and of "how social systems collapse, how they regain order, and what can be done to strengthen their resilience, so that they may be able to prevent a recurrence of violent conflict themselves, or at least to cope better with its effects" (de Coning 2016: 167). What is more, the focus on strengthening resilience among state organisations and local communities in violence-inflected societies, which represents anything but a straightforward endeavour, might in fact harbour the seeds of yet more failure. In this vein, Chandler observes that "at least international peacebuilding [...] forced a discussion of power and policy accountability on the agenda and thereby a discussion of the allocation of agency and responsibility to either internationals or locals. Pragmatic approaches of resilience remove this possibility of external accountability" (Chandler 2017: 187). Still others question whether peacebuilding as a "liberal" international governance

12 Alongside complexity, non-linearity, self-organisation and the impossibility of determining in any straightforward manner cause-effect relationships underlying contemporary violent conflict as well as efforts to overcome it through building peace, resilience has become a key notion in the sustaining peace discourse. In Cedric de Coning's words, "if a society is fragile, it means that the social institutions that govern its politics, security, justice and economy lack resilience. Resilience refers here to the capacity of these social institutions 'to absorb and adapt in order to sustain an acceptable level of function, structure and identity under stress. [...] From this perspective, sustaining peace should be about stimulating and facilitating the capacity of societies to self-organise, so that they can increase their ability to absorb and adapt to stress, to the degree necessary to sustain peace" (de Coning 1916: 173). 
project is effectively ending or whether it stands to persist, even in the face of adversity, owing to the West's powerful interests that have been driving it for decades, making it unlikely that peacebuilding as we have known it will be abandoned anytime soon (Pugh 2021).

Against the backdrop of these debates, which are reproduced here short-hand, it might be a telling fact that the UN secretary-general's annual reports on sustaining peace are at pains not to jettison the term "peacebuilding," which continues to enjoy ample official usage, and consistently replace it with the notion of "sustaining peace." Overcoming the old policy frameworks and institutional mindsets, even if only in semantic terms, thus seems to be more difficult than is commonly acknowledged. At the same time, it is noteworthy that the reforms geared towards providing the sustaining peace agenda an enabling institutional and organisational backbone remain mired in the traditional conception of the indivisibility of peace, human rights and development and their mutually reinforcing qualities.

For sure, no one who has worked to prevent, resolve or transform violent conflict through political, non-violent means would seriously deny that human rights and inclusive development are important in their own right and should serve as enablers for the building of constructive and trusting relationships between both individuals and groups in a society. However, they would also know that in many places human rights and development are contested and subject to historically entrenched power asymmetries that often manifest in, or bear the imprint of, different forms of direct, structural and cultural violence. It therefore appears that holding fast to universalist conceptions of human rights, development, democracy and the rule of law, which have underpinned "liberal" approaches to peacebuilding, and the premise that they reinforce one another under whatever circumstances risks undermining the goals of the emerging sustaining peace agenda. ${ }^{13}$

13 Based on my long-time experience as an analyst of violent conflict and political and other crises, I take the liberty to add here that the focus on conflict prevention rather than conflict resolution, which is said to characterise the sustaining peace agenda and differentiate it from previous approaches to peacebuilding, is not entirely new. Having spent the 2000s working on the ground with the International Crisis Group on helping to prevent the outbreak of, or the relapse into, violent conflict in countries such as Bolivia, Ecuador, Guatemala, Haiti and Venezuela, as well as trying to contribute to resolving intractable armed conflict by political means in Colombia, the argument that the focus of sustaining peace is novel because it is oriented towards violent conflict prevention 
This notwithstanding, even if contested and still lacking operational precision and internal coherence I suggest there are reasons for continuing to build our competences in the field of sustaining peace. According to my reading, the emerging paradigm signals both the hope and recognition that peace, if it is to be achieved in the face of adversity, can only emerge and persist if individuals and communities anywhere in the world muster the strength to believe in both its desirability and feasibility. Echoing John Paul Lederach's seminal work (Lederach 1997, 2005), this implies that people have access to, and command over, the appropriate tools that enable them to establish cooperative and trusting relationships among themselves and manage and/or transform their unavoidable conflicts without recurring to the use of force and violence. It is thus important to realise that changing the focus from building to sustaining peace not only reflects a "dark mood" (Kustermans et al. 2021) among decision-makers at the UN and in western capitals owing to the limited leverage they have with respect to influencing, let alone bringing about, persisting patterns of cooperation and trust in violence-inflected settings. ${ }^{14}$

True, the hitherto dominant recipe of building peace through the promotion-or imposition-of political democracy, the rule of law and free market economies modelled on liberal principles and standards has too often fallen short of producing solid, durable outcomes and preventing conflict relapse (see, for instance, Chandler 2017; Pugh 2021;

is not convincing. A host of non-governmental and multilateral organisations, including UN agencies, were actively engaged in conflict prevention prior to the emergence of the sustaining peace agenda.

14 The point about the "dark mood" has recently been driven home in Afghanistan. Following the badly planned and executed withdrawal of western troops after two decades of US-led allied military, security, political, development and other forms of intervention, which cost many Afghan civilians their lives and western taxpayers billions and billions of dollars while failing to produce even a degree of stability and improve the chances of a better life for common people, the Taliban did not face much trouble when proceeding to retake the country within a matter of weeks in the summer of 2021. Other examples, such as Mali, the Democratic Republic of the Congo and Iraq, readily illustrate what Jorg Kustermans and colleagues refer to as "peacebuilding's predicament" (Kustermans et al. 2021). 
UN General Assembly and Security Council 2015a). ${ }^{15}$ Also true, alternative "bottom-up" approaches to building peace characterised by more sensitivity to political, social, cultural and other conditions at the local level not only have found it hard to be incorporated into mainstream peacebuilding programming. In their own way, they too have not been able to provide convincing answers to the tough questions that peace poses and the compromises it demands from individuals and social groups in violence-inflected societies and states (see, for instance, Chandler 2017).

However, I suggest that there is more to the "dark mood" engulfing international peacebuilding. It signals something deeper than a sense of futility, of waging an uphill battle that cannot be won: it challenges us to take a harder look at peace itself. In this respect, it has correctly been pointed out that more is known about conflict and violence than about peace (Coleman 2012, 2013). As I have discussed earlier, peace is typically defined in relation to violence and war, not in its own right. In its negative form, it is understood to represent a state of social relationships in which war and diverse types of direct, structural and cultural violence are absent or contained. In its positive form, peace is conceived as being something more than the absence of violence and war (Galtung $1969,2012,2017)$. But there is no consensus among scholars as well as practitioners and decision-makers on what exactly the intrinsic properties of peace are, and how they shape-or do not-human attitudes, beliefs, behaviours and values, both at the individual and the collective levels as well as across cultures and peoples. In other words, to this day

15 In hindsight, let it be said, international peacebuilding always had a quixotic quality to it, standing little chance of "success." Needless to say, "success" here is a highly relative term dependent on how those who evaluate international peacebuilding outcomes and impacts define it. It should further be noted that national peacebuilding efforts, where the UN and other international or intergovernmental actors do not play a leading role but which nonetheless at their core pursue "liberal" goals, such as Colombia's current experience, too do not necessarily fare any better with respect to implementing peace accords, achieving the goals agreed by the former adversaries and preventing the continuation or relapse into violence. This would indicate that the forces of peacelessness embedded and reproduced in the social formations of societies and states (Galtung 2012) are indeed extremely hard to come by with the forces of peacefulness. 
peace, both as a concept and variable set of social and institutional practices, remains elusive, contested and in need of more empirically grounded theorisation. ${ }^{16}$

\subsubsection{Historical Memory-Oriented Peace Education and Sustaining Peace: Connecting the Dots}

This book is not the place to engage with the wider phenomenological and ontological debates about peace. Yet I believe that the sustaining peace agenda, as I have briefly described it above, offers an opportunity to take a fresh look at the ways in which we approach our applied, everyday work on and for peace in the classroom and beyond. Regarding the field of peace education, I suggest there is merit in adopting the less prescriptive, value-laden and universalising and, at the same time, more indeterminate, normatively restrained and humble elements that set the discourse on sustaining peace apart from that of conventional international peacebuilding. In this respect, it seems to me that incorporating a focus on historical memory can enhance the strength and value of education on and for peace in a world riven with crises, disunity and violent conflict. Rather than upholding notions of universal values, independent of local culture and historically formed power relationships, and the idea that peace can be achieved by righting the individual mind; or seeking to bring about far-reaching social transformation to alleviate the plight of the oppressed and marginalised by empowering them to resist and fight, such an approach strives to enable learners (and teachers)

16 Here it should be noted that authors like Galtung, Lederach and Coleman, to name but three scholars working in the field of contemporary peace studies, have gone to great lengths to provide the abstract notion of peace with more concrete meaning. For instance, in Galtung's "formula for peace by peaceful means" (Galtung 2017: 3) peace equals equity and harmony (numerator) divided by trauma and conflict (denominator): "the more equity and harmony the better; the more unreconciled trauma and unresolved conflict the worse" (Galtung 2012: 24). The idea of equity and harmony co-existing in a precarious and dynamic balance with trauma and conflict connects with Coleman's insight that peace and conflict should be understood as simultaneous social processes, not opposites (Coleman 2013). It also echoes Lederach's proposition of seeing peace as "not merely a stage in time or a condition [but as] [...] a dynamic social construct," where the promotion of non-violent, constructive relationships between the involved parties can be helped by the creation of "an infrastructure for sustaining the dynamic transformation of conflict" (Lederach 1997: 84). However enlightening they may be, these and similar theoretical propositions still need to be put to the test in empirical research. 
to work towards healing past trauma and recognising the "other" as a moral agent. Historical memory-oriented peace education thus seeks to promote reconciliation by opening up space for the surfacing and expression of emotions. More cooperative, trusting and harmonious relationships among individuals and collectives are enabled on the basis of new identities shaped by experiences of having witnessed and listened to the suffering of the "other."

Taken together, the sustaining peace agenda and the SDGs constitute a new international framework within which the quest for developing this novel approach to, and praxis of, historical memory-oriented education on and for peace can be developed. In effect, it is the framework that is available at present to pursue this goal-if the effort is made to strengthen the connections to, and increase its relevance for, the field of education in general and peace education in particular. Both the SDGs and the sustaining peace agenda do not omit referring to education. Yet it is notable that the topic is not addressed in either of them with the centrality it should be awarded. Under the title "Ensure inclusive and equitable quality education and promote lifelong learning opportunities for all," SDG 4, Target 4.7 specifies that "all learners [should be enabled to] acquire the knowledge and skills needed to promote sustainable development, including, among others, through education for sustainable development and sustainable lifestyles, human rights, gender equality, promotion of a culture of peace and non-violence, global citizenship and appreciation of cultural diversity and of culture's contribution to sustainable development (emphasis added)" (UN General Assembly 2015: 17). While the UN secretary-general's first two reports (2018, 2019) on the implementation of the sustaining peace agenda-surprisingly-do not include any reference to education, the one of 2020 mentions that in relation to "youth, peace and security" the "core challenges include structural barriers limiting the participation of young people and their capacity to influence decision-making; violations of their human rights; and insufficient investment in facilitating their inclusion, in particular through education. Prioritising education in approaches to peace, including conflict-sensitive curricula for peace and non-violence, is considered catalytic (emphasis added)" (UN General Assembly and Security Council 2020: 13).

While I agree with the statement that "prioritising education in approaches to peace, including conflict-sensitive curricula for peace and 
non-violence" is key, I am less convinced that in this respect it is expedient to put the spotlight in rather single-minded fashion on fostering a "culture of peace and non-violence." As discussed earlier, the UNESCOpromoted cultures of peace movement correctly points to the importance of not overlooking the broader social and cultural contexts in whichat any given time and in any given place-education in general and peace education in particular takes place. However, promoting a culture of peace through education has typically been framed as involving the shaping of attitudes, beliefs, behaviours and values of young people according to purportedly universal, enlightened precepts without offering much by way of addressing the structural causes and drivers of violence and war. Recall Wulf's reminder that "education for peace must continue to draw back on key concepts such as 'organised peacelessness,' 'structural violence' and 'social justice'” (Wulf 2018: 9).

To be effective, I have argued, the universalising, morally appellative and normative approach underpinning the wider field of conventional peace education, including that of helping to build a culture of peace, ought to be interrogated. Such interrogation is offered by diverse types of critical approaches to peace education. However, based on my grounded, long-time experience as a political analyst and university teacher in countries wrestling with, or emerging from, violent conflict I caution that critical peace education with its focus on empowering both individuals and collectives to become agents of structural social transformation geared towards enhancing social equity and justice and fight entrenched power relationships may in practice have antagonising and counterproductive effects. In this regard, it should not be overlooked that engaging in education on and for peace in violence-inflected countries and societies must pay more than lip service to the principle of "do no harm." In short, in settings like Colombia peace education of a critical kind is potentially dangerous for both learners and teachers. It also carries the risk of not reflecting sufficiently the very real and tangible challenges associated with learners' and teachers' everyday experiences of manifold manifestations of violence and injustice, thereby contributing to enhancing feelings of disempowerment or deepening prevailing antagonisms.

The practice of sustaining peace requires a broader, more versatile and reflexive approach to peace education. If we agree that sustaining rather than building peace is about strengthening the resilience of individuals and collectives in social environments characterised by complex 
and dynamically evolving adversity and risk-including manifold manifestations of direct, structural and cultural violence-that are difficult, perhaps even impossible to influence and transform from the outside; and if we agree that fomenting existing and creating new constructive and trusting relationships among individuals, and within and between collectives, that enable them to resolve and transform unavoidable conflicts by non-violent means in ways that reflect local cultural and other realities, constitutes the essence of the praxis of sustaining peace, then there is a case to be made that historical memory-oriented education on and/or for peace can support these processes. No doubt, working with historical memory in the classroom faces pitfalls. But if the paradoxes of, and tensions inherent in, historical memory are openly addressed it can free emotional and moral energies that neither conventional nor critical peace education can, thus supporting the emergence of new, inclusive identities and strengthening the resilience of individuals and groups vis-à-vis the ever-present spectre of the continuation or transformation of violent conflict.

\section{REFERENCES}

Arias, Rosa. "Elementos para pensar una educación para la paz integral." In Bitácora para la cátedra de la paz. Formación de maestros y educadores para una Colombia en paz, edited by Piedad Ortega, 243-262. Bogotá: Universidad Pedagógica Nacional, 2016.

Bekerman, Zvi, and Michalinos Zembylas. "Education and the dangerous memories of historical trauma: Narratives of pain, narratives of hope." Curriculum Inquiry 38, no. 2 (2008): 125-154.

Bekerman, Zvi, and Michalinos Zembylas. Teaching Contested Narratives. Identity, Memory and Reconciliation in Peace Education and Beyond. Cambridge: Cambridge University Press, 2012.

Bellino, Michelle. "Whose past, whose present? Historical memory among the "postwar" generation in Guatemala." In (Re)constructing Memory: School Textbooks and the Imagination of the Nation, edited by James Williams, 131-152. Rotterdam: Sense Publishers, 2014

Boulding, Elise. "Peace culture." In Toward a Compassionate Society, edited by Mahnaz Afkhami, 8-15. Bethesda, MD: Women's Learning Partnership, 2002.

Bull, Anna, and Hans Hansen. "On agonistic memory." Memory Studies 9, no. 4 (2016): 390-404. 
Cahill-Ripley, Amanda, and Diane Hendrick. Economic, social and cultural rights and sustaining peace: An introduction. Lancaster: Lancaster University Law School, 2018.

Chandler, David. Peacebuilding. The Twenty Years' Crisis, 1997-2017. Cham: Palgrave Macmillan, 2017.

Coleman, Peter. The Missing Piece in Sustainable Peace. New York: General Earth Institute, 2012.

Coleman, Peter. "Crises and opportunities: Six contemporary challenges for increasing probabilities for sustainable peace." International Journal of Conflict Engagement and Resolution 1, no. l (2013): 96-113.

Corredor, Javier, María Emma Wills, and Mikel Asensio-Brouard. "Historical memory education for peace and justice: Definition of a field." Journal of Peace Education 15, no. 2 (2018): 169-190.

De Coning, Cedric. "From peacebuilding to sustaining peace: Implications of complexity for resilience and sustainability." Resilience 4, no. 3 (2016): 166181.

Echevarría, Josefina, and Hilary Cremin. "Education for territorial peace in Colombia: What role for transrational peace?" Journal of Peace Education 16, no. 3 (2019): 316-338.

Galtung, Johan. "Violence, peace and peace research." Journal of Peace Research 6, no. 3 (1969): 167-191.

Galtung, Johan. A Theory of Peace: Building Direct Structural Cultural Peace. Oslo: Kolofon Press, 2012.

Galtung, Johan. 2017. "Peace: A peace practitioner's guide." Ideas for Peace 13: $1-16$.

Girón, Claudia. "La dimension psicosocial de la educación para la paz." In Bitácora para la cátedra de la paz. Formación de maestros y educadores para una Colombia en paz, edited by Pilar Ortega, 159-185. Bogotá: Universidad Pedagógica Nacional, 2016.

Goulah, Jason, and Olivier Urbain. "Daisaku Ikeda's philosophy of peace, education proposals, and Soka education: convergences and divergences in peace education." Journal of Peace Education 10, no. 3 (2013): 303-322.

Gur-Ze'ev, Ilan. "Philosophy of peace education in a postmetaphysical era." In Handbook on Peace Education, edited by Gavriel Salomon and Ed Cairns, 171-183. New York: Psychology Press, 2010.

Hagar, Tamar, and Rela Mazali. 2013. "Changing consciousness: Autoethnographic mapping in a dialogue group." Journal of Peace Education 10, no. 3 : 259-282.

Herrera, Martha, and Carol Pertuz. "Cuento para no olvidar." In Bitácora para la cátedra de la paz. Formación de maestros y educadores para una Colombia en paz, edited by Pilar Ortega, 187-218. Bogotá: Universidad Pedagógica Nacional, 2016. 
International Peace Institute. Sustaining Peace: What Does It Mean in Practice? New York: International Peace Institute, 2017 (2017a).

International Peace Institute. Human Rights and Sustaining Peace. New York: International Peace Institute, 2017 (2017b).

International Peace Institute. The Role of Local Governance in Sustaining Peace. New York: International Peace Institute, 2018.

Kelly, Rhys, and Ute Kelly. "An education in homecoming: peace education as the pursuit of 'appropriate knowledge'." Journal of Peace Education 10, no. 3 (2013): 283-302.

Kustermans, Jorg, Tom Sauer, and Barbara Segaert. 2021. "Peacebuilding's predicament: A dark mood among the experts." In A Requiem for Peacebuilding? Rethinking Peace and Conflict Studies, edited by Jorg Kustermans, Tom Sauer and Barbara Saegert, 1-14. Antwerp: University Centre SaintIgantius.

Lederach, John Paul. Building Peace. Sustainable Reconciliation in Divided Societies. Washington, DC: United States Institute of Peace Press, 1997.

Lederach, Johan Paul. The Moral Imagination. The Art and Soul of Building Peace. Oxford: Oxford University Press, 2005.

Leo, Per. Tränen ohne Trauer. Nach der Erinnerungskultur. Stuttgart: KlettCotta, 2021.

Manojlovic, Borislava. Education for Sustainable Peace and Conflict Resilient Communities Cham: Palgrave Macmillan, 2018.

Merchán, Jeritza. "La pedagogía en la Ley de Víctimas y en los posacuerdos de paz." In Bitácora para la cátedra de la paz. Formación de maestros y educadores para una Colombia en paz, edited by Pilar Ortega, 115-134. Bogotá: Universidad Pedagógica Nacional, 2016.

Metcalfe-Hough, Victoria, Alastair McKechnie, and Sara Pantuliano. Delivering the UN 'Sustaining Peace' Agenda, Briefing Note. London: Overseas Development Institute, 2017.

Ponzio, Richard. The UN's new "Sustaining Peace” Agenda: A Policy Breakthrough in the Making (2018). https://www.stimson.org/2018/un-new-sus taining-peace-agenda-policy-breakthrough-making/.

Pugh, Michael. "Peacebuilding's origins and history." In A Requiem for Peacebuilding? Rethinking Peace and Conflict Studies, edited by Jorg Kustermans, Tom Sauer, and Barbara Saegert, 17-40. Antwerp: University Centre SaintIgantius, 2021.

Riaño, Pilar, and María Uribe. "Construyendo memoria en medio del conflicto. El Grupo de Memoria Histórica en Colombia." Revista de Estudios Colombianos 50 (2017): 9-23.

Sánchez, Gonzalo. Guerra, memoria e historia. Medellín: La Carreta Histórica, 2006. 
Sánchez, Gonzalo. "Memorias en tiempos de polarización política.” In Gonzalo Sánchez. Memorias, subjetividades y politica. Ensayos sobre un pais que se niega a dejar la guerra, 11-26. Bogotá: Editorial Planeta Colombiana S.A., 2019.

Schultze-Kraft, Markus. Crimilegal Orders, Governance and Armed Conflict. Cham: Palgrave Macmillan, 2019.

Schultze-Kraft, Markus. "Integration through education in Colombia: An expatriate's view from the field." Unpublished typescript, 2021.

Torres, Ingrid. "Pedagogías de la memoria y la enseñanza de la historia para la construcción de una conciencia histórica." In Bitácora para la cátedra de la paz. Formación de maestros y educadores para una Colombia en paz, edited by Pilar Ortega, 263-282. Bogotá: Universidad Pedagógica Nacional, 2016.

UN General Assembly. Transforming Our World: The 2030 Agenda for Sustainable Development. A/RES/70/1, 21 October 2015.

UN General Assembly. Resolution Adopted by the General Assembly on 27 April 2016. Review of the United Nations Peacebuilding Architecture. A/RES/70/262, 12 May 2016.

UN General Assembly and Security Council. Challenge of Sustaining Peace. Report of the Advisory Group of Experts on the Review of the Peacebuilding Architecture, A/69/968-S/2015/490, 30 June 2015 (2015a).

UN General Assembly and Security Council. Comprehensive Review of the Whole Question of Peacekeeping Operations in All Their Aspects. Comprehensive review of Special Political Missions. Strengthening of the United Nations System. A/69/968-S/2015/490, 30 June 2015 (2015b).

UN General Assembly and Security Council. Peacebuilding and Sustaining Peace. Report of the Secretary-General. A/72/707-S/2018/43, 18 January 2018.

UN General Assembly and Security Council. Peacebuilding and Sustaining Peace. Report of the Secretary-General. A/73/890-S/2019/448, 30 May 2019.

UN General Assembly and Security Council. Peacebuilding and Sustaining Peace. Report of the Secretary-General. A/74/976-S/2020/773, 30 July 2020.

UN Security Council. Resolution 2282 (2016). Adopted by the Security Council at Its 7680th Meeting, on 27 April 2016. S/RES/2282 (2016), 27 April 2016.

UN and World Bank. Pathways for Peace: Inclusive Approaches to Preventing Violent Conflict. Washington, DC: World Bank, 2018.

World Bank. World Development Report 2011: Conflict, Security, and Development. Washington DC: International Bank for Reconstruction and Development/World Bank, 2011.

Wulf, Christoph. "Culture of peace and education for peace." In Culture of Peace. A Contribution to UNESCO's Educational Mission: Building Peace in the Minds of Men and Women, 6-14. Berlin: UNESCO Club Berlin/UNESCO Associated Schools in Germany, 2018. 
Open Access This chapter is licensed under the terms of the Creative Commons Attribution 4.0 International License (http://creativecommons.org/licenses/ by $/ 4.0 /$ ), which permits use, sharing, adaptation, distribution and reproduction in any medium or format, as long as you give appropriate credit to the original author(s) and the source, provide a link to the Creative Commons license and indicate if changes were made.

The images or other third party material in this chapter are included in the chapter's Creative Commons license, unless indicated otherwise in a credit line to the material. If material is not included in the chapter's Creative Commons license and your intended use is not permitted by statutory regulation or exceeds the permitted use, you will need to obtain permission directly from the copyright holder.

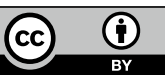

